\title{
き裂を有する䝨斜機能平板の熱応力解析*
}

\author{
野田直剛*1, 倉田哲男*2, 淵山隆*3 \\ 过知 章*1, 小畑 良 洋*4
}

\section{Thermal Stress Analysis in Functionally Gradient Plate with a Crack}

\author{
Naotake NADA, Tetsuo KURATA, Takashi FUCHIYAMA, \\ Tomoaki TSUJI and Yoshihiro OBATA
}

\begin{abstract}
Functionally gradient materials (FGMs) are advanced high-temperature materials capable of withstanding extreme temperature enviroments, and are produced by continuous change of two material components. In this work a FGM plate of PSZ and $\mathrm{Ti}-6 \mathrm{Al}-4 \mathrm{~V}$ is suddenly heated and suddenly cooled on the ceramic surface side and is kept cool on the metal surface side. The transient thermal stress and the stress intensity factors are calculated by a finite-element method (FEM). Crack propagation from an edged crack on the surface of ceramics side and the optimum distribution of materials are shown and discussed from the calculated thermal stress and stress intensity factors.
\end{abstract}

Key Words: Functionally Gradient Material, Thermal Stress, Themal Shock, Crack Propagation, Stress Intensity Factor, Finite-Element Method

\section{1. 緒}

宇宙・原子力等の分野において, 超高温化・超高速化 に対応した新しい材料として, 熱応力緩和形傾斜機能 材料(FGM) が研究開発されている. 熱応力緩和形傾斜 機能材料は，七ラミックスから金属へ連続的に組成を 変化させることによって, 耐熱性・高強度・高遮熱性を 兼ね備えることを目的とした材料である。

傾斜機能材料の研究については, 野田・过(1)(2) は傾 斜機能平板の定常熱応力について物性值の温度依存性 を考慮しない場合と考虑した場合とについて理論解析 を行っている. 小畑ら(3)(4) は傾斜機能平板の非定常熱 応力について理論解析を行い, 最大引張応力が冷却時 に発生することを示している. 有限要素法を用いた研 究では, 淵山・野田ら ${ }^{(5)}$ は, 加熱・冷却 1 サイクル熱負 荷を受ける円板の非定常熱応力解析を行っている. また, 日比野・川崎ら (6) や, 川崎・渡辺ら ${ }^{(7)}$ は, 傾斜機 能材料の加熱実験を行い, 加熱条件によっては熱応力 により傾斜機能材料のセラミックス側表面にき裂が発

* 原稿受付 1995 年 11 月 17 日.

*1 正員, 静岡大学工学部 (632 浜松市城北 3-5-1).

*2 静岡大学大学院.

*3 正員, ススキ(株)実験解析部（西 432-91 浜松市高塚市 300).

*4 正員, 名古屋工業技術研究所 ( 462 名古屋市北区平手町 1).
生することを報告している.このような熱衝撃を受け る傾斜機能材料に発生したき裂の進展を検討するに は，破壊力学的検討が必要であるが, 具体的な例につ いて，破壇力学的検討はいまだ行われていない。

本論文では有限要素法を用いて，き裂を有する傾斜 機能平板の非定常熱応力解析を行う. 傾斜機能平板に 発生するき裂は冷却初期にセラミックス表面で発生す ることを考慮して ${ }^{(7)}$, 温度拘束によりセラミックス表 面を加熱・冷却し，金属表面をつねに冷却する熱衝释 の解析を行う。さらに，セラミックス表面の加熱条件 を変えた場合の最適組成について，応力分布から検討 するとともに, き裂を有する場合について応力拡大係 数からも検討する.

\section{2. 解 析}

図 1 に示すように, 上面が部分安定化ジルコニウム (PSZ)，下面が Ti-6Al-4V からなるき裂を有する傾 斜機能平板を考える。ただし図 1 において， $T_{0}$ ：初期 温度, $T_{a}: \mathrm{Ti}-6 \mathrm{Al}-4 \mathrm{~V}$ の表面温度, $T_{b}: \mathrm{PSZ}$ の表面 温度, $a$ : 初期き裂長さである.傾斜機能平板の組成成 分は中心軸 ( $x$ 軸) 上に治って連続的に傾斜していると する. 金属の体積分率 $V_{m}$ は無次元化座標 $X(=x / h$, $h$ : 板厚)を用いて式( 1 )のように表されるとする. 
$V_{m}=X^{m}$

体䅡分率パラメー夕 $m$ の変化による金属の体積分率 $V_{m}$ を図示すれば，図 2 のようになる。

傾斜機能平板の各位置における物性值は混合則(5) により与えられるとし, PSZ と Ti-6Al-4V の物性值

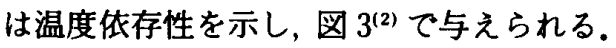

温度の境界条件はセラミックス側上面が全面加熱さ れ, 定常状態に達した後, 瞬時に表面温度を初期温度 $300 \mathrm{~K}$ まで急冷した場合を考える，また，金属表面は つねに $300 \mathrm{~K}$ に保持され，側面は断熱状態とする。一 方, 力学的境界条件は自由境界条件とする。冷却初期 にセラミックス側に大きな引張応力が発生するのて， セラミックス表面に初期き裂長さ $a$ を有する傾斜機 能平板とする。

有限要素法に使用した要素は, 8 節点二次のアイソ パラメトリック要素を用い, き裂先端には特異要素を 用いて解析を行った。物性值は節点に対し与え, 要素 内で二次の形状関数により補間した。

傾斜機能材料のような連続的に組成が変化する不均 質材料の応力㹡大係数については, Erdogan ら ${ }^{(10)}$, 野 田・ $\operatorname{Jin}^{(11)(12)}$ が, き裂先端近傍の応力の特異性は均質 材料の場合と同様に $r^{-1 / 2}$ の特異性をもつことを示し ている.図 4 のような局座標系において $y$ 方向変位 $v$ とモードIの応力拡大係数 $K_{I}$ の関係は式 ( 2 )で表さ れるから, 応力拡大係数 $K_{1}$ は, 有限要素法で求めた 変位から式 $(2)$ を用いて, $r \rightarrow 0$ に外捙して求めた。

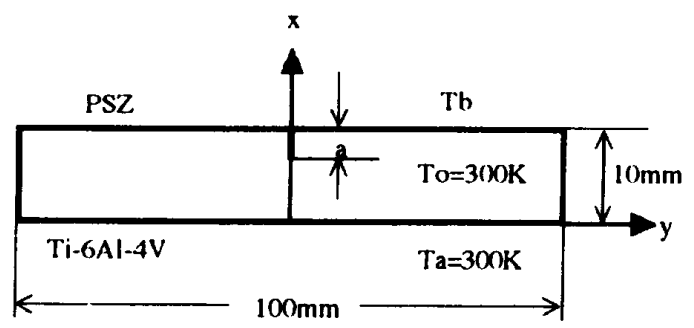

Fig. 1 Functionally gradient plate with an edge crack

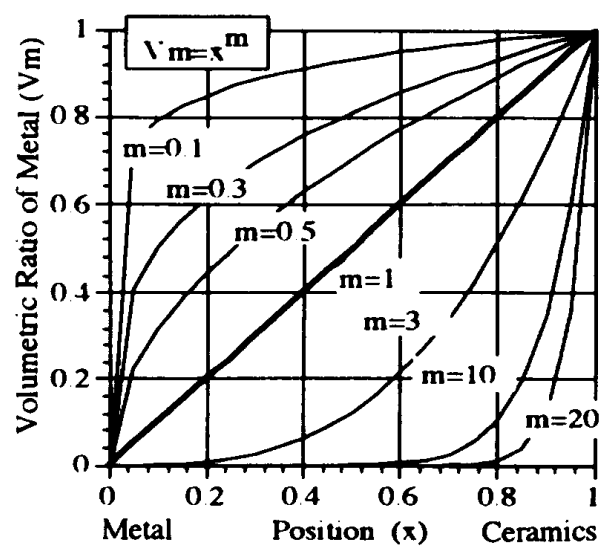

Fig. 2 Volumetric ratio of metal versus aposition

$$
v=\frac{K_{I}}{G} \sqrt{\frac{r}{2 \pi}} \sin \frac{\theta}{2}\left(2-2 \nu-\cos ^{2} \frac{\theta}{2}\right) \cdots
$$

ただし，G：横弾性係数, レ：ポアソン比である。

\section{3. 応力を基䈖とした最迨組成分布}

き裂を有する傾斜機能平板の非定常熱応力解析を行 うにあたり，まずき裂がない場合の傾斜機能平板の非 定常熱応力解析を行い, 応力份布から傾斜機能平板の 最適組成分布について解析を行う。セラミックス表面 の加熱温度が $T_{b}=1300 \mathrm{~K}$ の場合, 体積分率パラメー 夕 $m$ が 1.0 のとき，すなわち組成が直線的に変化する 場合の傾斜機能平板の冷却時の中心軸上 $(y=0)$ の熱 応力の時間変化を図 5 に示す。また, 応力を引張強さ

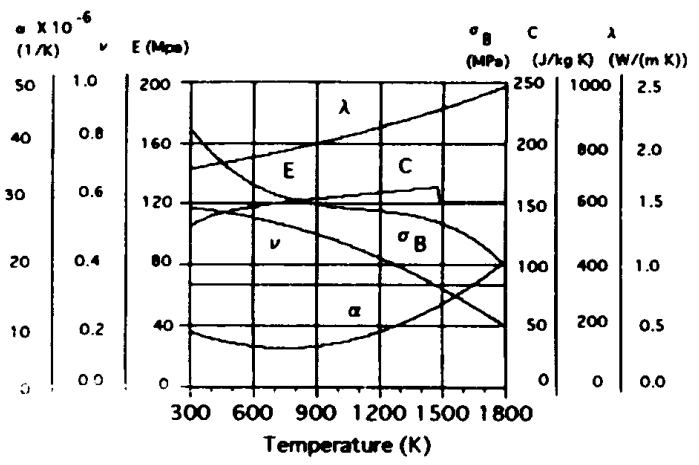

(a) PSZ

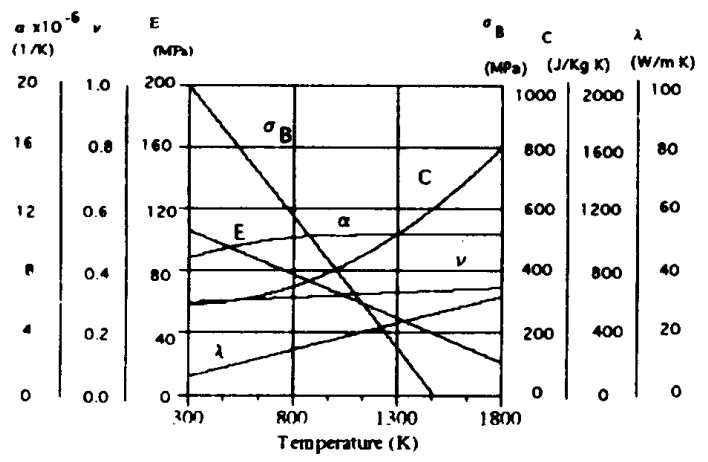

(b) $\mathrm{Ti}-6 \mathrm{Al}-4 \mathrm{~V}$

Fig. 3 Material properties

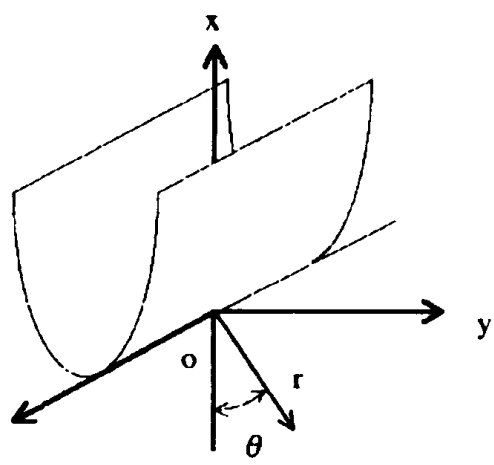

Fig. 4 Coordinate system from a crack tip 
$\sigma_{b}$ で除した応力比を図 6 に示す. 両図より, 最大引張 応力は冷却初期にセラミックス表面に生じ, セラミッ クス表面上の引張熱応力は時間の経過とともに減少 し, 定常状態で零となっていくことがわかる. 最大引 張応力が引張強さ $\sigma_{b}$ より大きい場合破壊が生じると すれば, 応力比が 1 より大きな場合に破壊が起きるこ とになる. 熱衝撃を受ける傾斜機能材料は冷却初期に セラミックス表面から破壊が起こり, 図6よりセラミ ックス表面から約 $0.7 \mathrm{~mm}$ まで破壊が進むと予想さ れる.

最大引張応力がセラミックス表面に冷却初期に発生 することより, セラミックス表面上の最大引張応力が 体積分率パラメータ $m$ (傾斜組成分布)によりいかに 変化するかを考える。そこで, 体積分率パラメータ $m$ とセラミックス表面上の最大引張応力の関係を加熱温 度 $T_{b}$ をパラメータとして図 7 に示す. 図 7 よりどの

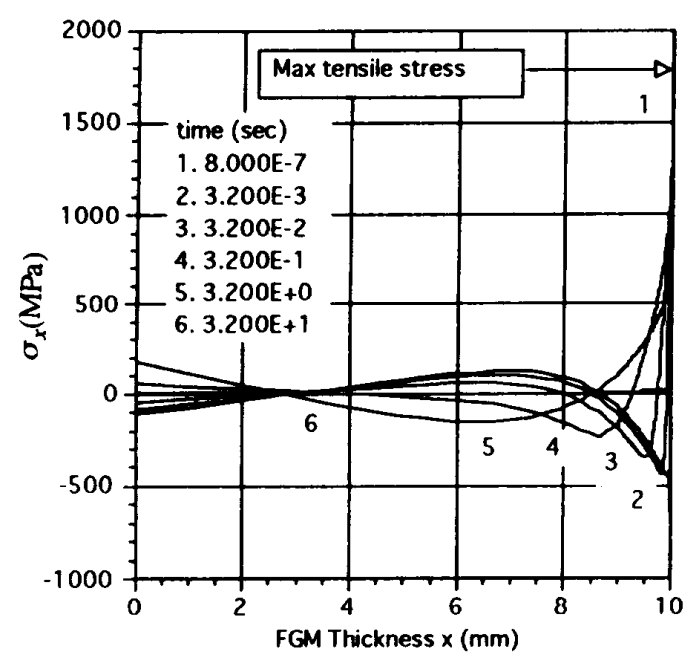

Fig. 5 Thermal stress at cooling stage

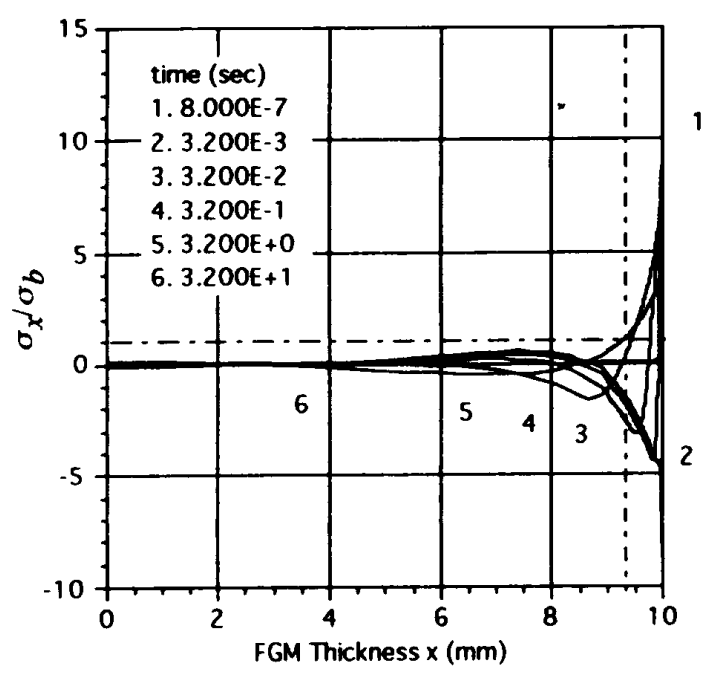

Fig. 6 Stress ratio $\left(\sigma_{x} / \sigma_{b}\right)$ at cooling stage
加熱温度 $T_{b}$ においても最大引張応力は，体積分率パ ラメータ $m$ が 1.0 のとき，すなわち組成分布が直線 的に変化するとき, 最小となっていることがわかる.

引張強さ $\sigma_{b}$ は温度の関数であるから, 引張強さ $\sigma_{b}$ で無次元化したセラミックス表面上の応力比と体積分 率パラメータ $m$ の関係を加熱温度 $T_{b}$ をパラメータ として図 8 に示す. 図 8 よりどの加熱温度 $T_{b}$ におい ても応力比は, 体積分率パラメータ $m$ が 1.0 のとき, すなわち組成分布が直線的に変化する場合に最小とな っており,引張強さを基準とした最適組成分布は直線 分布であることがわかる。すなわち，組成分布を適切 に選ふことにより，熱衝慗によって傾斜機能平板に発 生する熱応力が纊和されることがわかる.

\section{4. き裂を有する傾斜撳能平板}

き裂を有する傾斜機能平板の非定常熱応力について 考える.冷却時のき裂伝ぱモデルを図 9 に示す.図 9 は 時間をパラメータとし応力拡大係数と初期き裂長さの 関係を示したものである. 応力拡大係数が破壊靶性值 より大きいときき裂が伝ぱするとすれば, 初期き裂長

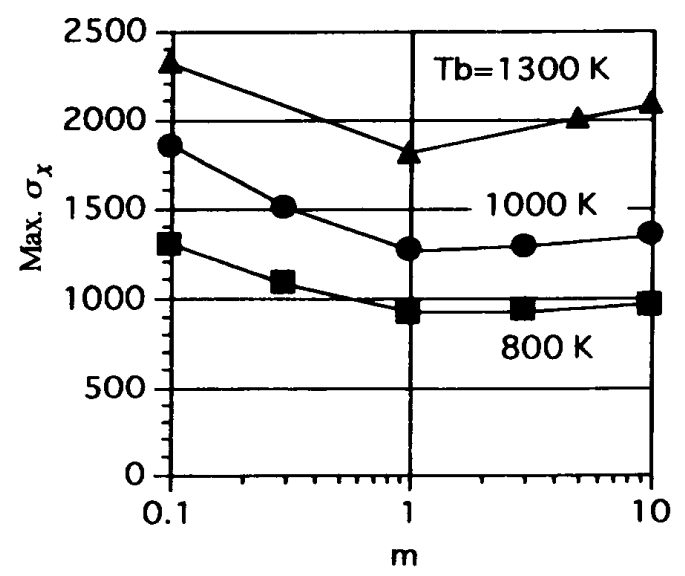

Fig. 7 Maximum stress versus parameter of volumetric ratio $m$

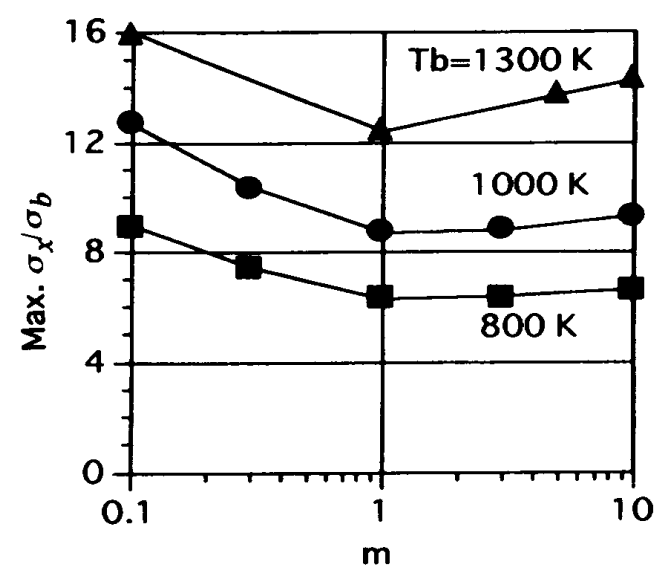

Fig. 8 Maximum stress ratio versus $m$ 
さ $a_{0}$ を有する傾斜機能平板は冷却開始後時間 $t_{3}$ まで はき裂は伝ぱせず，時間 $t_{3}$ を経過し，応力㹡大係数が 破懐鞄性值 $K_{\mathrm{IC}}$ を越えてからき裂伝ぱを開始し，瞬時 にき裂長さ $a_{1}$ までき裂が伝ぱする.すなわち不安定き 裂伝ぱを行う。その後, 時間が経つにつれ安定き裂伝 ぱを行い, 時間 $t_{4}$ においてき裂長さ $a_{2}$ までき裂伝ぱ した後，き裂成長は停止する。

本解析では，セラミックス表面を $T_{b}=1300 \mathrm{~K}$ で加 熱し定常状態になった後, $300 \mathrm{~K} て ゙$ 急冷したときの, 冷却時の応力拡大係数の変化から傾斜機能平板のき裂 伝ぱについて考える。ここでは，金属の体稹分率パラ メータ $m=1.0$ (き裂を有しない傾斜機能平板の最適組 成分布)のとき傾斜機能平板と, PSZ 平板のき裂伝ぱ について解析を行い, 応力㹡大係数の変化を求め, き 裂伝ぱモデルと同様に安定・不安定き裂伝ぱについて 検討し, FGM 平板と PSZ 平板の結果を比較・検討す る.

図 10 と図 11 にき裂長さと応力拡大係数の関係の数 値計算結果を示す. 図 10 は体積分率パラメータ $m=$

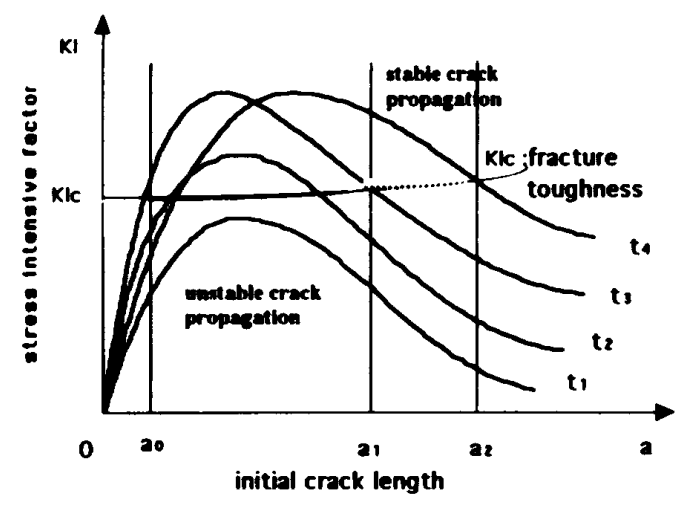

Fig. 9 Model of crack propagation

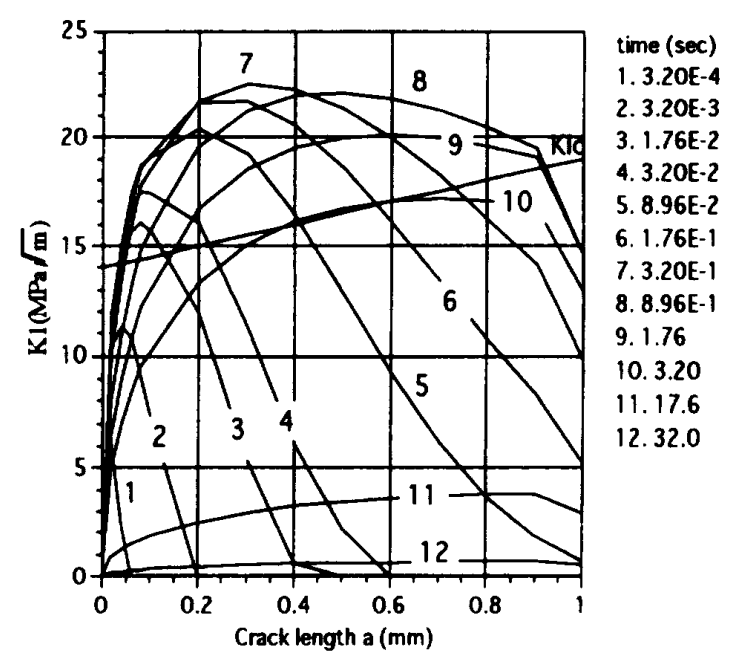

Fig. 10 Stress intensity factor $K_{1}$ at various crack length with time
1.0 の傾科機能平板のき裂長さと応力拡大係数の関係 について, 図 11 にはPSZ のみからなる平板のき裂長 さと応力拡大係数の関係について, 冷却時間をパラメ 一タとして表示している.き裂伝ぱは応力拡大係数が 破壤䩗性值 $K_{\mathrm{I}}$ 以上のときに起こるとし，傾斜機能平 板の破壊勒性值は位置の関数であるので, 体積分率 $V_{m}$ を用いて式(3)で与えられるとする。

$$
K_{\mathrm{IC}}=V_{m} K_{\mathrm{IC} \text { metal }}+\left(1-V_{m}\right) K_{\mathrm{IC} \text { ceramics }}
$$

ただし， $K_{\mathrm{IC} \text { metal }}$ 金属の破烄靶性值，KIC ceramics はセ ラミックスの破壊䩘性值である.PSZ の破壊鞄性值は $14 \mathrm{MPa} \sqrt{m}^{(13)}, \mathrm{Ti}-6 \mathrm{Al}-4 \mathrm{~V}$ の破壊鞄性値は $64 \mathrm{MPa}$ $\sqrt{m}^{(14)}$ であるとする。

図 10 の傾斜機能平板のき裂長さと応力㹡大係数の 関係から，熱衝拲を受ける傾斜機能平板は初期き裂長 さが $a_{0}=0.04 \mathrm{~mm}$ のとき, 時間 $t=0.032 \mathrm{~s} て ゙$ 不安定き 裂伝ぱを開始し, およそ $0.22 \mathrm{~mm}$ まで不安定き裂伝 ぱを行う.その後, 安定き裂伝ぱをセラミックス表面 から約 $0.9 \mathrm{~mm}$, 時間 $t=1.76 \mathrm{~s}$ まで行い, き裂后ばは 停止する。一方, PSZ 単層平板のき裂伝ぱは図 11 か ら, 初期き裂長さ $a_{0}=0.02 \mathrm{~mm}$, 時間 $t=0.032 \mathrm{~s}$ で不 安定なき裂伝ぱを開始し,およそ $0.27 \mathrm{~mm}$ まで不安 定き裂伝ぱを行う。その後, 安定き裂伝ぱを約 2.7 $\mathrm{mm}$, 時間 $t=3.2 \mathrm{~s}$ まで行い, き裂伝ぱは停止する.

傾斜機能平板と PSZ 平板のき裂伝ぱについて比較 すると,き裂伝ぱを開始するための最小初期き裂長さ は傾斜機能平板のほうが長く，き裂伝ぱが停止する距 離は傾斜機能平板のほうが短い.また, 応力拡大係数 の最大值は傾斜機能平板が $22.5 \mathrm{MPa} \sqrt{m}, \mathrm{PSZ}$ 平板 が $30.0 \mathrm{MPa} \sqrt{m}$ と傾斜機能平板のほうが小さい。こ れらから, 傾斜機能平板はPSZ 単層平板よりき裂伝

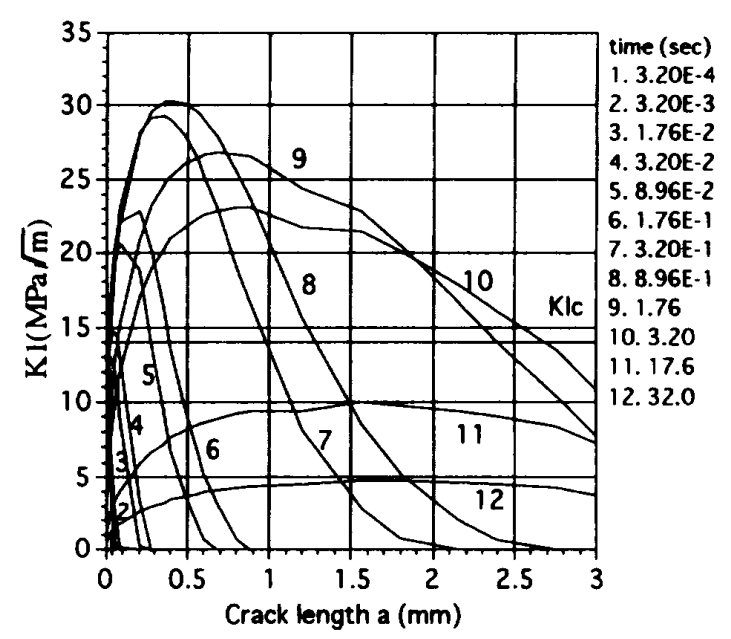

Fig. 11 Stress intensity factor of a ceramic plate 
ぱが開始しにくく，き裂伝ぱしにくい材料であるとい える。

\section{5.き裂を有する俱斜機能平板の 最这組成分布}

セラミックス表面が瞬時に $T_{b}$ まで加熱され, 定常 状態に達した後, セラミックス表面を瞬時に初期温度 まで冷却される傾斜機能平板の最適組成分布について 破壊力学的立場から検討する。 まず体積分率パラメー 夕 $m=1.0$ の傾斜機能平板の加熱温度 $T_{b}$ を変化させ た場合, 加熱温度 $T_{b}$ がき裂伝ぱに及はす影䉕につい て検討をする. 図 12 に加熱温度 $T_{b}$ がき裂長さと応力

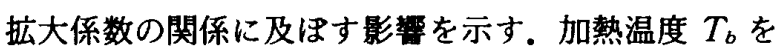
$800 \mathrm{~K}, 900 \mathrm{~K}, 1000 \mathrm{~K}, 1300 \mathrm{~K}$ と変化させたとき, 加熱温度が高くなるほど応力拡大係数は大きくなり， またき裂伝ぱが開始する初期き裂長さは短くなり，さ らにき裂伝ぱが停止する距離は長くなる，つまり，加 熱条件 $T_{b}$ が高いほど，き裂伝ぱしやすく，かつき裂

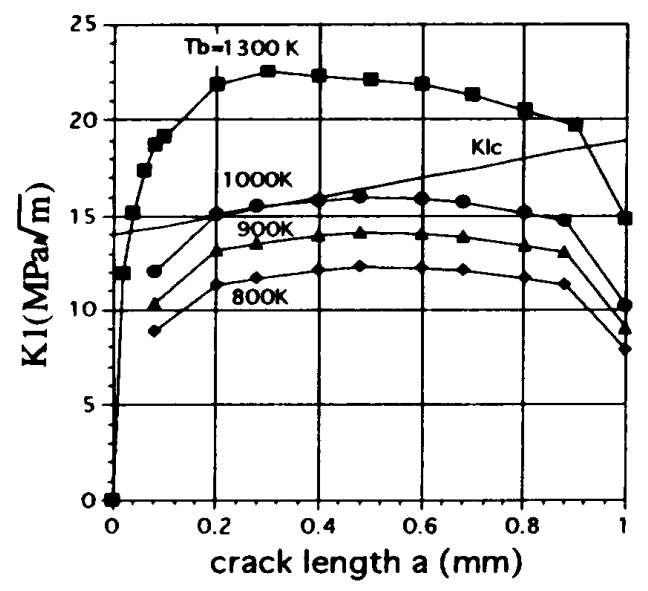

Fig. 12 Maximum stress intensity factor at various crack length

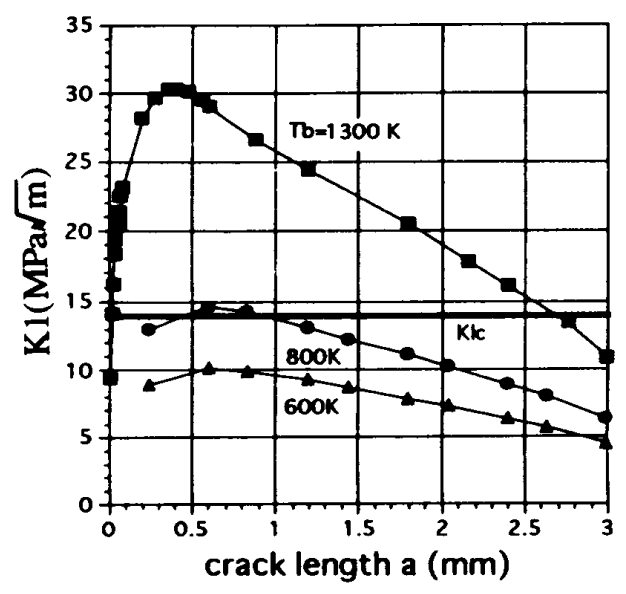

Fig. 13 Maximum stress intensity factor of a ceramic plate
長さが長くなることがかかる，また図 12 より，直線組 成分布の傾斜機能平板に破䁲が生じる加熱温度 $T_{b}$ は 約 $1000 \mathrm{~K}$ 以上のときであることがわかる.

一方 PSZ 単層平板に対し, 加熱温度 $T_{b}$ を変えた場 合のき裂長さと応力拡大係数の関係を図 13 に示す.加 熱温度 $T_{b}$ を $600 \mathrm{~K}, 800 \mathrm{~K}, 1300 \mathrm{~K}$ と変化させた場 合, 傾斜機能平板の場合と同様に, 加熱温度 $T_{b}$ が高 いほど応力拡大係数は大きくなり，き裂伝ぱが開始す る初期き裂長さは短くなり，き裂伝ぱが停止する距離 は長くなる.図 13 より, PSZ 単層平板に破垻が起こる のは加熱温度 $T_{b}$ が約 $800 \mathrm{~K}$ 以上のときであることが わかる。

直線組成分布の傾斜機能平板と PSZ 平板の応力拡 大係数を比較して，破壤が起こるときの加熱温度 $T_{b}$ は直線組成分布の傾斜機能平板は約 $1000 \mathrm{~K}, \mathrm{PSZ}$ 単 層平板は約 $800 \mathrm{~K}$ と, 直線組成分布の傾斜機能平板の ほうが破壤が開始する温度が高く，また同一温度条件 のとき，傾斜機能平板は PSZ 単首平板よりき裂長さ が短いことがわかる。このことより，傾斜機能平板は PSZ 単層平板より高温度に耐え, かつき裂が伝ぱしに くい材料であるといえる。

次に，加熱条件 $T_{b}$ ・体積分率パラメー夕 $m$ を変え た場合の最大応力拡大係数について解析を行い, 加熱 温度を変えた場合に最適組成分布を与える体積分率パ ラメータ $m$ について検討する. 図 12 において, 応力 抬大係数の最大值を最大応力㹡大係数 $K_{\mathrm{I} \text { max }}$ とし, 加 熱温度 $T_{b}$ を $800 \mathrm{~K}, 1000 \mathrm{~K}, 1300 \mathrm{~K}$ とした場合の体 積分率パラメー夕 $m$ と最大応力係数 $K_{\mathrm{I} \max }$ の関係を 図 14 に示す. 図 14 から $m$ が一定のときに, 加熱温度 $T_{b}$ が高いほど $K_{\mathrm{I} \max }$ は大きくなることがわかる．ま

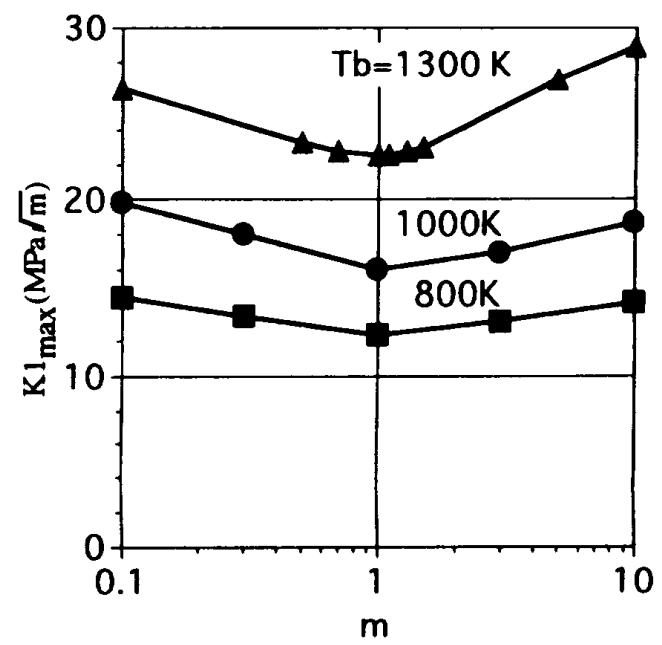

Fig. 14 Maximum stress intensity factor versus $m$ 
た，各加熱温度 $T_{b}$ において $K_{\mathrm{Imax}}$ が最小となる $m$ の 值は $m=1.0$ のとき，すなわち線形組成分布のときで あることがわかる. 以上より，加熱・冷却を受ける傾斜 機能材料の最適組成は線形組成分布であると言える. このように，セラミックスと金属の組成分布を適切に 選ふことにより最大応力㹡大係数を減少させることが できる。

\section{6. 結}

セラミックス側に PSZ，金属側に Ti-6Al-4V を用 いたき裂を有する傾斜機能平板が加熱・冷却を受ける 場合について，物性値の温度依存性を考虑して非定常 熱弹性解析を行い，熱衝擊を受ける傾斜機能平板のき 裂伝ぱと, 各種加熱温度に対する傾斜機能平板の最適 組成分布を求めた結果以下の結論を得た。

（1）き裂(初期き裂長さ $a_{0}=0.04 \mathrm{~mm}$ )を有する直 線組成分布の傾斜機能平板が加熱温度 $T_{b}=1300 \mathrm{~K}$ の熱衝擊を受けるとき，傾斜機能平板はき裂長さ $a=$ $0.22 \mathrm{~mm}$ まで不安定き裂层ぱを起こし, その後安定き 裂伝ぱに変化し,き裂伝ばは $a=0.9 \mathrm{~mm}$ で停止する.

（2）熱重撃を受ける直線組成分布の傾斜機能平板 と PSZ 単層平板のき裂伝ばについて比較すると，熱 衝撃に対して直線組成分布の傾斜機能平板は PSZ 単 層平板より高温度に耐え，かつき裂が伝ぱしにくい材 料であるといえる。

（3）傾斜機能平板の組成分布を適切に選ふことに より，最大引張応力および最大応力拡大係数とも緩和 することが可能である。
（4）引張強さおよび破壊鞄性を強度基準として も, 傾斜機能平板の最適組成分布は線形組成のときて あると言える。

\section{文献}

（1）野田直刚 - 辻知章, 機論, 57-533, A (1991), 98-103.

（2）野田直网・辻知章, 機論, 57-535, A(1991)，625-631.

（3）小烟良洋·野田直剛・辻知章, 機論, 58-553, A (1992)，16891695.

（4）小畑良洋·野田直㣚・过知章, 機論, 59-560, A(1993)，10901103.

（5）淵山隆 - 野田直刚 - 过知章 - 小畑良洋, 機論, 59-564, A (1993), 131-136.

（6）日比野敦・川崎宽，渡辺龍三，第 4 回傾斜機能材料シンポ ジウム諈演集, (1991-10), 311-314.

(7) Kawasaki, A. and Watanabe, R. (Schneider, G. A. and Retzow, G. 編), Thermal Shock and Thermal Fatigue Behavior of Advanced Ceramics, (1993), 509-520, Kluwer Academic Fub.

(8) H-ABahr,ほ加 4 名 (Schneider, G. A. and Petzow, (G. 論), Thermal Shock and Thermal Fatigue Behavior of Advanced Ceramics, (1993), 105-107, Kluwer Academic Pub.

(9) Schneider, G. A., ほか 3 名 (Schneider, G. K. and Petzow, G. A. 編), Themral Shock and Thermal Fatigue Behavior of Advanced Ceramics, (1993), 229-244, Kluwer Academic Pub.

(10) Erdogan, F., Trans. ASME, J. Appl. Mech., 58, (1991), 410-418.

(11) Noda, N., and Jin, J.-H., Trans. ASME, J. Appl. Mech., 61-3, (1994), 738-740.

（12）野田直刪 - Jin, J.-H., 㙨論, 60-572, A (1994), 921-925.

(13)阿部弘・ほか 3 名(山口喬・柳田博明蝙), エンジニアリン グセラミックス，(1976)，24，技報堂出版.

（14）矢川元基，破壊力学，(1988），263，培風館. 